\title{
Stabilization and Improvement of Energy Storage Performance of High Mass Loading Cobalt Hydroxide Electrode by Surface Functionalization
}

Jacob Olchowka, ${ }^{* a, c, d}$ Ronan Invernizzi, ${ }^{a}$ Alexia Lemoine, ${ }^{b}$ Joachim Allouche, ${ }^{\text {b,c }}$ Isabelle Baraille, ${ }^{\mathrm{b}}$ Delphine Flahaut, ${ }^{\mathrm{b}, \mathrm{c}}$ Liliane Guerlou-Demourgues, ${ }^{\mathrm{a}, \mathrm{c}, \mathrm{d}}$

${ }^{a}$ CNRS, Univ. Bordeaux, Bordeaux INP, ICMCB UMR CNRS \#5026, F-33600, Pessac, France.

${ }^{\mathrm{b}}$ CNRS/Univ. Pau \& Pays Adour / E2S UPPA, Institut des Sciences Analytiques et de Physicochimie pour l’Environnement et les Matériaux - UMR 5254, 64000 Pau, France

c RS2E, Réseau Français sur le Stockage Electrochimique de l’Energie, FR CNRS \#3459, F-80039 Amiens Cedex 1, France.

d ALISTORE-ERI European Research Institute, FR CNRS \#3104, Amiens, F-80039 Cedex 1, France.

Keywords: Supercapacitors; Electrochemical energy storage; Surface modification; Cobalt hydroxide; Ionic Liquids

Abstract: Nano oxides and hydroxides generate great interest as promising positive electrode materials for the development of high energy density supercapacitors. However, their usually limited ionic and electronic conductivities significantly decrease their energy storage performances when increasing the electrode's mass loading. Here, we report on a sonochemical approach to functionalize the surface of $\mathrm{Co}(\mathrm{OH})_{2}$ nanomaterials by $\mathrm{EmimBF}_{4}$ ionic liquid that greatly improves the stability and the electrochemical performances of high mass loading electrodes $\left(13 \mathrm{mg} / \mathrm{cm}^{2}\right)$. This surface functionalization boosts the transport properties and strongly enhances the capacity as well as the capacity retention at higher current densities compared to basic $\mathrm{Co}(\mathrm{OH})_{2}$ (e.g. $113.5 \mathrm{C} / \mathrm{g}$ vs. $59.2 \mathrm{C} / \mathrm{g}$ at $1 \mathrm{~A} / \mathrm{g}$ ). Additionally, the protective layer formed by the ionic liquid stabilizes the electrode material upon cycling in $\mathrm{KOH}$ aqueous electrolyte and protects the material from oxidation upon open-air storage. 
One of the biggest challenge in supercapacitor research area consists in increasing their energy density, which is, in the current supercapacitors, still limited for several applications into renewable energy storage or transport sector. A possible way to face this challenge is to develop high capacitance electrodes based on nanostructured pseudocapacitive or battery-like materials. ${ }^{1}$ Indeed, the latter materials have the ability to achieve rapid redox reactions that can deliver a higher energy density than adsorption/desorption mechanisms currently observed for carbon-based electrodes used in the commercial EDLC. ${ }^{2}$ These last years, different oxides/hydroxides such as $\mathrm{RuO}_{2}, \mathrm{MnO}_{2}, \mathrm{Co}_{3} \mathrm{O}_{4}, \mathrm{Ni}(\mathrm{OH})_{2}, \mathrm{Co}(\mathrm{OH})_{2}, \mathrm{NiCo}_{2} \mathrm{O}_{4}$, have been studied for that purpose. ${ }^{2,3}$ Among these materials, cobalt hydroxide has attracted attention due to its layered structure that allows a good ionic mobility, its high theoretical capacity $(2076 \mathrm{C} / \mathrm{g}$ considering 2 electrons exchange) and relatively low cost. Additionally, Deng et al. determined recently that the oxidation/reduction processes generate only minor structural changes enabling excellent rate performances and high cycling life. ${ }^{4}$ Cobalt hydroxide can be synthesized in two different phases: the $\alpha$-form is described as positively charged $\mathrm{Co}(\mathrm{OH})_{2-\mathrm{x}}$ sheets separated by interlayered anions $\left(\mathrm{NO}_{3}{ }^{-}, \mathrm{Cl}^{-} \ldots\right)$ to compensate the charge and the brucite-like $\beta$-form of $\mathrm{Co}(\mathrm{OH})_{2}$, which is reported as a hexagonal close-packed structure of hydroxyl ions with $\mathrm{Co}(\mathrm{II})$ occupying octahedral interstices one plane out of two. ${ }^{5,6}$ In the $\alpha$-form, the presence of anionic species together with water molecules generates bigger interlayered spacing compared to those in $\beta-\mathrm{Co}(\mathrm{OH})_{2}$, however the $\alpha-\mathrm{Co}(\mathrm{OH})_{2}$ is metastable and quickly evolve to $\beta$-form in alkaline solution. $^{7}$

Various synthesis approaches such as sol-gel, hydrothermal, precipitation or electrodeposition leading to different original morphologies of nanostructured $\operatorname{Co}(\mathrm{OH})_{2}$ or hybrid carbon- $\mathrm{Co}(\mathrm{OH})_{2}$ materials are reported in the literature. For instance, Ranganatha et al. reported a sol-gel synthesis of mesoporous $\alpha-\mathrm{Co}(\mathrm{OH})_{2},{ }^{8}$ Wang et al. synthesized flower-like $\alpha$ $\mathrm{Co}(\mathrm{OH})_{2}$ by precipitation method, ${ }^{9} \mathrm{Fu}$ et al grown pine needle $\mathrm{B}-\mathrm{Co}(\mathrm{OH})_{2}$ on nickel foam, ${ }^{10}$ and Darbandi et al. communicated on the preparation of $\beta-\mathrm{Co}(\mathrm{OH})_{2}$ nanorings by chemical precipitation. ${ }^{11}$ Although these electrode materials reported in the literature present most of the time good electrochemical performances and high specific capacities, the active material mass loading used in these studies is usually very low and not adapted for real devices (see Table 1). In fact, electrode mass loading should be above $10 \mathrm{mg} . \mathrm{cm}^{-2}$ in hybrid supercapacitors in order to validate the gravimetric capacity of full devices and the absence of study with adequate mass loading does not allow to evaluate the real potentiality of $\mathrm{Co}(\mathrm{OH})_{2}$ electrode material. ${ }^{12,13}$ It is well known that increasing mass loading leads usually to increase the charge transfer resistance 
and to slow down ionic diffusion, that finally lowers the specific capacity. ${ }^{14,15}$ For instance Jagadale et al. reported for $\alpha-\mathrm{Co}(\mathrm{OH})_{2}$ a drastic drop in capacitance from $386.4 \mathrm{~F} \cdot \mathrm{g}^{-1}$ (193 C.g ${ }^{1}$ ) to $150 \mathrm{~F}^{-g^{-1}}\left(75 \mathrm{C}^{-\mathrm{g}^{-1}}\right)$ for a slight increase in electrode active mass loading (from 2.5 to 3.1 mg.cm-2). ${ }^{16}$ Similarly, Ranganatha et al. have shown that the specific capacitance is consequently lowered when increasing mass loading levels (mass loading of 0.5-0.6 mg. $\mathrm{cm}^{-2}$, 2.4-2.5 mg.cm ${ }^{-2}$ and 4.7-4.8 mg.cm ${ }^{-2}$ lead to a capacitance of $\sim 450 \mathrm{~F} . \mathrm{g}^{-1}, \sim 270 \mathrm{~F} \cdot \mathrm{g}^{-1}$ and $\sim 150$ F. g $^{-1}$ respectively). ${ }^{17}$

To face this problem and optimize the transport properties, the surface modification of the active material could be an ideal issue. For instance, a surface modification by ionic liquids (IL) "functionalization" can reshape the surface properties or bring new ones (e.g. hydrophobicity), alter the interface reactivity or reduce the surface defects. ${ }^{18-20}$ Concerning the conduction properties, the group of Tarascon found that $\mathrm{LiZnSO}_{4} \mathrm{~F}-\mathrm{IL}$, synthesized by ionothermal approach, exhibits a RT ionic conductivity four orders of magnitude higher than the basic $\mathrm{LiZnSO}_{4} \mathrm{~F}^{21}$ Interestingly, Choi et al. have also demonstrated by DFT calculations that the functionalization of $\mathrm{Co}(\mathrm{OH})_{2}$ surface by the $\mathrm{BmimBF}_{4}$ ionic liquid permits faster ion diffusion and easier hydrogen adsorption/desorption processes on $\mathrm{Co}(\mathrm{OH})_{2} .{ }^{22}$ However, in their work, the synthesized nanohybrid material, $\mathrm{Co}(\mathrm{OH})_{2}$-IL, has a different size/morphology and a 6 time higher specific surface area than their benchmark $\mathrm{Co}(\mathrm{OH})_{2}$, which makes impossible to evaluate experimentally the sole influence of the surface modification on the ionic diffusion and energy storage performances. ${ }^{22}$ Additionally, the mass loading of their electrode was not high enough for practical application. In this work, we develop a sonochemical assisted method to synthesize $\mathrm{Co}(\mathrm{OH})_{2}$-IL nanohybrids and investigate the influence of the surface functionalization on the energy storage performances of high mass loading electrodes (13 mg.cm-2), by comparing $\mathrm{Co}(\mathrm{OH})_{2}$-IL with the benchmark $\mathrm{Co}(\mathrm{OH})_{2}$ material of similar size/morphology. EmimBF 4 (1-ethyl-3-methylimidazolium tetrafluoroborate) was chosen for this study due to its higher conductivity compared to $\mathrm{BmimBF}_{4}$ (1-butyl-3-methylimidazolium tetrafluoroborate) and other imidazolium based ionic liquids with longer alkyl chains. ${ }^{23}$ 
Synthesis: $\mathrm{Co}(\mathrm{OH})_{2}$-IL was prepared by ionic liquid assisted sonochemical method. In a first step, $3.18 \mathrm{~g}$ of $\mathrm{Co}\left(\mathrm{NO}_{3}\right)_{2} .6 \mathrm{H}_{2} \mathrm{O}$ were dissolved in a mixture of $5 \mathrm{~mL}$ of $\mathrm{H}_{2} \mathrm{O}, 5 \mathrm{~mL}$ of ethanol and $2 \mathrm{~mL}$ of EmimBF 4 (1-ethyl-3-methylimidazolium tetrafluoroborate), then $10 \mathrm{~mL}$ of $3 \mathrm{M}$ $\mathrm{NaOH}$ was added to the cobalt solution. Immediately after the addition, the solution was sonicated during $30 \mathrm{~min}$ (with pulses of $7 \mathrm{~s}$ "on" and $3 \mathrm{~s}$ "off"). The pink powder was then collected by centrifugation, washed several times in ethanol and dried at $60^{\circ} \mathrm{C}$ overnight. The same procedure was done without IL to obtain the benchmark $\mathrm{Co}(\mathrm{OH})_{2}$.

XRD analyses: A Philips Panalytical X'Pert Pro diffractometer was used to record X-ray powder diffraction patterns. A Co $\mathrm{K}_{\alpha}$ radiation was used in order to avoid fluorescence problematic with traditional Copper sources and to generate high quality patterns. The powder diffraction patterns were recorded for about $4 \mathrm{~h}$ in the $10^{\circ}-110^{\circ}(2 \theta)$ angular range, with a $0.0167^{\circ}(2 \theta)$ step size and a $2.122^{\circ}(2 \theta)$ active width in the detector.

Scanning electron microscopy (SEM) images were taken on the metallized samples (Pddeposited) by a Hitachi Model S-4500 microscope.

Fourier transform infrared (FT-IR) spectra were recorded by using a Bruker Equinox 55 spectrometer in the wavenumber range of $400-4000 \mathrm{~cm}^{-1}$ (mid-IR) with a resolution of $4 \mathrm{~cm}^{-1}$. The samples were finely ground in a mortar with dried $\mathrm{KBr}$ in an approximate ratio of 1: 40 (by wt.\%).

XPS experiment: The X-ray photoelectron spectroscopy analyses (XPS) were performed with the Thermo K-alpha spectrometer with a hemispherical analyzer and a microfocussed monochromatized radiation $\mathrm{Al} \mathrm{K}_{\alpha}$ line $(1486.6 \mathrm{eV})$ operating at $75 \mathrm{~W}$ under a residual pressure of $1 \times 10^{-7} \mathrm{mBar}$. The analysis area was ca. $200 \mu \mathrm{m}^{2}$ and a pass energy of $20 \mathrm{eV}$ was used for core peak records. The use of neutralizer gun, which sprays the low energy electrons and $\mathrm{Ar}^{+}$ ions over the sample surface, to minimize the surface charging was necessary. All the binding energies were referenced to the $\mathrm{C} 1 \mathrm{~s}$ peak at $285.0 \mathrm{eV}$ originating from the adventitious carbon (always detected at surface of materials). Core peaks were analysed using a nonlinear Shirleytype background and peak positions and areas were obtained by a weighted least-squares fitting of model curves (70\% Gaussian, 30\% Lorentzian) to the experimental date. Quantification of surface composition was based on Scofield's relative sensitivity factors. ${ }^{24}$ 
The Auger Electron Spectroscopy (AES) analyses were carried out with a JEOL JAMP 9500F Auger spectrometer (JEOL Ltd, Tokyo, Japan) working under UHV conditions (pressure < $\left.2.10^{-7} \mathrm{~Pa}\right)$. The UHV equipment was a Schottky field emission Auger electron spectrometer (FE-AES) allowing a high lateral resolution ( $10 \mathrm{~nm})$ analysis and a high brightness.

AES spectra (kinetic energy from 0 to $1000 \mathrm{eV}$ ) were carried out at a constant retarding ratio $(\mathrm{CRR})$ mode with $\mathrm{dE} / \mathrm{E}=0.5 \%$ (high sensibility) at an acceleration voltage of $15 \mathrm{keV}$ and a probe current of $5 \mathrm{nA}$ (working distance $=23 \mathrm{~mm}$ and sample tilt angle $=30^{\circ}$ ).

Scanning Auger Maps (SAM) were recorded at constant retarding ratio (CAE) operating conditions and an acceleration voltage of $15 \mathrm{keV}$ with a probe current of $5 \mathrm{nA}$ (working distance $=23 \mathrm{~mm}$ and sample tilt angle $=30^{\circ}$ ).

Electrochemical measurements were performed in aqueous $5 \mathrm{M}-\mathrm{KOH}$ electrolytes in a three electrode mode at room temperature. Platinum wire was used as counter electrode whereas $\mathrm{Hg} / \mathrm{HgO}$ was used as reference electrode in the basic electrolyte. The working electrodes were prepared with a mixture of active material / carbon black / polytetrafluoroethylene in a weight ratio of 80/15/5. A disk of about $7 \mathrm{~mm}$ diameter of the electrode material, with a weight of $\sim 8$ $\mathrm{mg}$, was pressed during $30 \mathrm{~s}$ at 5 bars on a nickel foam (current collector). It results in a $8 \mathrm{~mm}$ disk and hence an active material loading of $\sim 13 \mathrm{mg} / \mathrm{cm}^{2}$. The three electrodes (working electrode, reference electrode and counter electrode) were placed in the electrolyte in order to form an equilateral triangle and each electrode was separated from the two others by $\approx 16 \mathrm{~mm}$. Electrochemical impedance measurements were performed under open-circuit condition. A small AC perturbation amplitude of $10 \mathrm{mV}$ versus the open-circuit potential was applied in a frequency range from $50 \mathrm{kHz}$ down to $0.1 \mathrm{~Hz}$. Cyclic Voltammetry (CV), Constant Current Charge/Discharge (CCCD) and Electrochemical Impedance Spectroscopy (EIS) were performed using a EC-lab potentiostat.

Results: Both syntheses (with and without ionic liquid) lead to pure and well crystallized B$\mathrm{Co}(\mathrm{OH})_{2}$ as it is confirmed by X-ray diffraction (see Figure 1a) and deduced from the pink color of the polycrystalline powders. The presence of the ionic liquid during the sonochemical synthesis does not influence the nature of the polymorph as in the hydrothermal synthesis reported by Jana et al. ${ }^{25}$ and has no influence on the morphology as in the synthesis approach reported by Choi et al. ${ }^{22}$ Indeed, figure 2 shows that both $\mathrm{Co}(\mathrm{OH})_{2}$ and $\mathrm{Co}(\mathrm{OH})_{2}-\mathrm{IL}$ are characterized by polydispersed platelets with a width ranging from about 50 to $300 \mathrm{~nm}$. During 
the synthesis, the ionic liquid does not hinder the platelets growing and/or Ostwald ripening that should be induced by the heating of the synthesis media and particle's collision generated by ultrasound radiations. ${ }^{26}$ In fact, the precipitation of $\mathrm{Co}(\mathrm{OH})_{2}$ happens directly after introducing the sodium hydroxide in the cobalt solution (see Figure S1) and the IL is rather used as reactant to generate the surface modification. Additional experiments reveal that the $\alpha$ polymorph can also be formed with this synthesis method by replacing $\mathrm{Co}(\mathrm{NO})_{3} \cdot 6 \mathrm{H}_{2} \mathrm{O}$ by $\mathrm{CoCl}_{2}$ (see Figure S2).

Figure $1 \mathrm{~b}$ shows the infrared spectra of $\mathrm{Co}(\mathrm{OH})_{2}$ and $\mathrm{Co}(\mathrm{OH})_{2}$-IL. For both materials, the sharp band at $\sim 3629 \mathrm{~cm}^{-1}$ ( $\mathrm{\vee}_{\mathrm{OH}}$ : stretching of the free hydroxyl groups) and the broad signal peaking at $530 \mathrm{~cm}^{-1}$ attributed to Co-O stretching perfectly fit with to the spectrum of $B$ $\mathrm{Co}(\mathrm{OH})_{2} \cdot{ }^{27}$ For $\mathrm{Co}(\mathrm{OH})_{2}-\mathrm{IL}$, the additional signals corresponding to $v_{\mathrm{B}-\mathrm{F}}\left(\sim 1084 \mathrm{~cm}^{-1}\right)$, $v_{\mathrm{C}-\mathrm{N}}$ $\left(\sim 1569 \mathrm{~cm}^{-1}\right)$ and $v_{\mathrm{C}-\mathrm{H}}$ (between 2900 and $\left.3200 \mathrm{~cm}^{-1}\right)$ confirm the presence of EmimBF 4 even after several washing steps, ${ }^{18,28}$ whereas the low intensity peak at $2425 \mathrm{~cm}^{-1}$ could be attributed to boron-oxygen bonds. These latter might be formed by the reaction between the decomposition products of $\mathrm{BF}_{4}{ }^{-}$and the solvent, indeed $\mathrm{BF}_{4}{ }^{-}$can be partially decomposed under ultrasonic radiation and generate $\mathrm{F}^{-}$ions. ${ }^{18,29}$ The band around $1384 \mathrm{~cm}^{-1}$ belongs to $\mathrm{N}-\mathrm{O}$ stretching vibrations of nitrates that are adsorbed on the particle surface of $\mathrm{Co}(\mathrm{OH})_{2}$ during the synthesis. $^{4}$

XPS survey has been first recorded, and the orbitals of the elements coming from the $\mathrm{Co}(\mathrm{OH})_{2}$ materials and from the ionic liquid have been detected (see Figure 3). High-resolution spectra have also been obtained for all the orbitals of the elements detected. The corresponding binding energies (B.E.) and atomic percentages are reported in Table 2.

Co $2 \mathrm{p}$ spectrum exhibits two main components due the spin-orbit coupling located, respectively, at $780.5 \mathrm{eV}$ for the Co $2 \mathrm{p}_{3 / 2}$ and $797.0 \mathrm{eV}$ for the Co2 $\mathrm{p}_{1 / 2}$. Two large peaks, assigned to shake-up satellites, located at $5.7 \mathrm{eV}$ toward the higher binding energies can also been detected. Lower satellites are also observed at $790.6 \mathrm{eV}$ and $806.5 \mathrm{eV}$. The energy position, the FWHM and the area ratio between the satellites and the main component $\left.\left(\mathrm{I}_{\mathrm{Co2psa}} / \mathrm{I}_{\mathrm{Co2pmain}}\right) \sim 0.8\right)$ indicates that the cobalt is in the +2 oxidation state in a hydroxyl environment. ${ }^{30}$ The $\mathrm{O} 1 \mathrm{~s}$ spectrum is decomposed in three components: the hydroxyl groups of the bulk materials is assigned to the major component at $531.1 \mathrm{eV}$. Two other minor 
components are attributed to oxide (B.E. O $1 \mathrm{~s}=529.1 \mathrm{eV}$ ) and oxygen from adsorbed species (B.E. O $1 \mathrm{~s}=532.5 \mathrm{eV}$ ).

The N 1s, F 1s and B 1s core peaks are directly associated to the presence of the ionic liquid on the $\mathrm{Co}(\mathrm{OH})_{2}$ surface. The $\mathrm{BF}_{4}{ }^{-}$environment is assigned, from the literature, ${ }^{31}$ to the component located at $194.6 \mathrm{eV}$. The second component at $192.0 \mathrm{eV}$ should be due to the boron atom in an oxygenated environment. This latter supports the partial decomposition of the $\mathrm{BF}_{4}^{-}$upon sonification as deduced from IR spectrum (see Figure 1b). Two components are also detected in the $\mathrm{F} 1 \mathrm{~s}$ core peaks one at $686.5 \mathrm{eV}$ for the fluorine in the $\mathrm{BF}_{4}{ }^{-}$anions, and the other at 684.3 $\mathrm{eV}$ due to chemisorbed fluorine on the material surface. ${ }^{32}$ The ratio between the fluorine and the boron assigned to the " $\mathrm{BF}_{4}^{--"}$ " environment reaches 3.2. The imidazolium $\mathrm{N}$ 1s signal of the cation is well detected at $401.9 \mathrm{eV}$ in accordance with the literature. ${ }^{33}$

The C 1s spectrum (not shown here) exhibits three components attributed to the hydrocarbonated species $(285 \mathrm{eV})$, the $\mathrm{C}-\mathrm{O}$ and $\mathrm{C}-\mathrm{N}$ environments $(286.5 \mathrm{eV})$ and the adsorbed species $(289.2 \mathrm{eV})$.

Finally, in addition to the Infrared data, the XPS analyses confirm the grafting of the ionic liquid on the $\mathrm{Co}(\mathrm{OH})_{2}$ materials surface with a $\mathrm{I}(\mathrm{N} 1 \mathrm{~s} 401.9) / \mathrm{I}(\mathrm{Co} 2 \mathrm{p})$ ratio of 0.08 . These results are also supported by Auger analyses revealing on several single $\mathrm{Co}(\mathrm{OH})_{2}$ particles nitrogen and boron signals corresponding to the ionic liquid fingerprint (see Figure S3).

In order to investigate the effect of the surface modification on the energy storage performances, galvanostatic charge/discharge (GCD), cyclic voltammetry (CV) as well as electrochemical impedance spectroscopy (EIS) measurements were performed on both $\mathrm{Co}(\mathrm{OH})_{2}$ and $\mathrm{Co}(\mathrm{OH})_{2}$-IL electrode materials. The influence of the nickel foam on the capacity was investigated and can be considered as negligible (see Figure S4). The CV curves (see Figure 4a) show that the two materials present two highly reversible oxidation peaks that might be assigned, according to the literature, to the oxidation of $\mathrm{Co}$ and leading to $\mathrm{H}_{\mathrm{x}} \mathrm{CoO} 2$ phases. ${ }^{34,35}$ The functionalization of $\mathrm{Co}(\mathrm{OH})_{2}$ surface by $\mathrm{EmimBF}_{4}$ triggers higher intensity oxidation and reduction peaks, leading to a higher capacity. Additionally, it seems to induce a slight shift of the redox peaks that lowers the polarization upon cycling (especially for P2/P'2: $0.12 \mathrm{~V}$ and $0.085 \mathrm{~V}$ for $\mathrm{Co}(\mathrm{OH})_{2}$ and $\mathrm{Co}(\mathrm{OH})_{2}$-IL respectively), suggesting a higher reversibility and better kinetics. The GCD curves (see Figure $4 \mathrm{~b}$ ) confirm the battery-like signature and the increased specific capacity for the hybrid material. This latter, evaluated from the discharge curve, is 113.5 C/g at $1 \mathrm{~A} / \mathrm{g}$ for $\mathrm{Co}(\mathrm{OH})_{2}-\mathrm{IL}$ against $59.2 \mathrm{C} / \mathrm{g}$ at $1 \mathrm{~A} / \mathrm{g}$ for $\mathrm{Co}(\mathrm{OH})_{2}$. Besides the capacity is nearly doubled for the functionalized material, the capacity retention when increasing the 
current density is also improved (see Figure 4c-d). For instance at $5 \mathrm{~A} / \mathrm{g}$, the capacity is maintained at $96.8 \mathrm{C} / \mathrm{g}$ (85.7\% of capacity retention compared to the capacity at $1 \mathrm{~A} / \mathrm{g}$ ) whereas it is only at $39 \mathrm{C} / \mathrm{g}\left(67 \%\right.$ of capacity retention) for the bare $\mathrm{Co}(\mathrm{OH})_{2}$.

In order to deeper investigate the effect of the ionic liquid, $\mathrm{CV}$ measurements at various scan rate were performed (see Figure S5). The evolution of the intensity versus the scan rate was further analyzed using the power-law relation (equation (1)):

$$
i(V)=\alpha v^{b}
$$

Here $i$ is the intensity at a defined potential $V, \alpha$ and $b$ are two constant and $v$ is the scan rate value. Based on the work done by the groups of Dunn and Long, ${ }^{36-38}$ a plot of $\log (i)$ versus $\log (v)$ allows to determine to the $b$-value which gives useful information about the transport dynamics and the charge storage mechanism. A $b$-value of 1 corresponds to a surface limited process (e.g. adsorption of ions / capacitive storage) whereas a $b$-value of 0.5 indicates a charge storage mechanism limited by semi-infinite diffusion (solid-state diffusion of cations through the electrode material / faradaic charge storage). We study the b-value using the cathodic currents with sweep rate ranging from $2 \mathrm{mV} / \mathrm{s}$ to $20 \mathrm{mV} / \mathrm{s}$. At a potential of $\mathrm{E}=0.15 \mathrm{~V}$ (see Figure 5a), which corresponds mainly to a faradaic region, the $b$-value of 0.5 for $\mathrm{Co}(\mathrm{OH})_{2}$ traduces a purely semi-infinite diffusion mechanism whereas the surface functionalization of $\mathrm{Co}(\mathrm{OH})_{2}$ by $\mathrm{EmimBF}_{4}$ leads to a $b$-value of 0.72 . This higher b-value suggests a more surface limited charge storage mechanism and/or limited diffusion mechanism. At $\mathrm{E}=0.33 \mathrm{~V}$ (see Figure 5b), which should rather correspond to (pseudo)capacitive region, the b-value of 1 for $\mathrm{Co}(\mathrm{OH})_{2}$-IL confirms a surface limited process whereas the lower b-value $(0.68)$ is rather characteristic of a finite diffusion process. Although the high mass loading electrodes (13 mg. $\left.\mathrm{cm}^{2}\right)$ may influence the b-value, in both regions $\mathrm{Co}(\mathrm{OH})_{2}$-IL presents better kinetics. Indeed, a synergic effect happens between the $\mathrm{Co}(\mathrm{OH})_{2}$ and the $\mathrm{EmimBF}_{4}$ which has a high intrinsic conductivity $\left(15 \mathrm{mS} . \mathrm{cm}^{-2}\right)$ that optimizes the transport properties of the hybrid material. ${ }^{39}$ These obtained results fit well to the theoretical calculations, which conclude that the adsorption/desorption of the proton is facilitated by the ionic liquid. ${ }^{22}$

For a better comprehension of the interfacial processes, EIS measurements were performed at open-circuit potential. Nyquist plots of $\mathrm{Co}(\mathrm{OH})_{2}$ and $\mathrm{Co}(\mathrm{OH})_{2}$-IL, represented figure $5 \mathrm{c}$, are characterized by a semi-circle at high frequencies corresponding to the charge transfer resistance $\left(\mathrm{R}_{\mathrm{CT}}\right)$ at the interfaces and a slope at low frequencies assigned to Warburg impedance $\left(\mathrm{Z}_{\mathrm{W}}\right.$ ). The trend of the $\mathrm{R}_{\mathrm{CT}}$ value, obtained using the equivalent circuit represented in the inset, 
suggests that the ionic liquid optimizes the interfacial exchanges $\left(\mathrm{R}_{\mathrm{CT}}=1.35 \Omega\right.$ and $1.9 \Omega$ for $\mathrm{Co}(\mathrm{OH})_{2}-\mathrm{IL}$ and $\mathrm{Co}(\mathrm{OH})_{2}$ respectively) (See Table S1 for data refinement). Although the particle's size and morphology as well as the cationic part of the ionic liquid differ, these values are close to the ones reported by Choi et al. (1.53 $\Omega$ and $2.59 \Omega$ for the nanohybrids and the bare material respectively). The hydrid material electrode presents also better diffusion properties that are characterized by a more vertical Warburg slope at low frequencies (Figure 5c). Finally, the surface modification induces a better stability of the electrode material upon long-term cycling and thus, a better capacity retention. Indeed, for $\mathrm{Co}(\mathrm{OH})_{2}$-IL the charge transfer resistance does not evolve after 5000 cycles at $2 \mathrm{~A} / \mathrm{g}$ whereas it strongly increases for $\mathrm{Co}(\mathrm{OH})_{2}$ (Figure 5c and Table S1). Similarly, the impact of long-term cycling on the ionic diffusion is detrimental for $\mathrm{Co}(\mathrm{OH})_{2}$ whereas it is nearly negligible for $\mathrm{Co}(\mathrm{OH})_{2}-\mathrm{IL}$. Figure $5 \mathrm{~d}$ shows the capacity evolution for both electrode materials upon long-term cycling performed at $2 \mathrm{~A} / \mathrm{g}$ in $5 \mathrm{M}-\mathrm{KOH}$. For $\mathrm{Co}(\mathrm{OH})_{2}-\mathrm{IL}$, the slight increase of capacity (from 105 to $110 \mathrm{C} / \mathrm{g}$ ) that happens during the first 500 cycles can be attributed to an activation process. Then, the capacity remains nearly constant during 5000 cycles, which, together with the excellent coulombic efficiency, attest the great electrode material stability already observed by EIS. On the other hand, the capacity of $\mathrm{Co}(\mathrm{OH})_{2}$ progressively decreases upon cycling to reach a capacity retention of $73 \%$ after 5000 cycles. Thus, it can be reasonably supposed that the electrode material directly starts to degrade upon cycling. From the EIS and long-term cycling analyses, it can be assumed that the better transport properties for $\mathrm{Co}(\mathrm{OH})_{2}$-IL prevent from mechanical constraints that induce a degradation of the material upon cycling

It is very important to highlight that the surface functionalization of $\mathrm{Co}(\mathrm{OH})_{2}$ nanomaterials not only improves the stability upon long-term cycling and the energy storage performance, but it also protects the material against moisture and oxidation under air. Figure 1a shows the XRD patterns of both $\mathrm{Co}(\mathrm{OH})_{2}$ and $\mathrm{Co}(\mathrm{OH})_{2}$-IL after 8-month open air storage. The bare $\mathrm{Co}(\mathrm{OH})_{2}$ phase becomes black (see Figure S6) and is completely oxidized in a mixture of $\mathrm{HCoO}_{2}$ and spinel $\mathrm{Co}_{3} \mathrm{O}_{4}$ whereas $\mathrm{Co}(\mathrm{OH})_{2}$-IL is perfectly stable. ${ }^{40}$ This induces that the IL acts as a protective layer against oxidation and it seems to cover homogeneously the material since no structural evolution could be detected after 8-month air exposure.

To summarize, the XPS, Auger and infrared analyses confirmed that we were able to functionalize the surface of $\mathrm{Co}(\mathrm{OH})_{2}$ with $\mathrm{EMIMBF}_{4}$ ionic liquid. The comparison of energy storage performances with the not functionalized material shows that this surface modification produces a synergetic effect between the highly conductive ionic liquid and the $\mathrm{Co}(\mathrm{OH})_{2}$ 
extremely beneficial for the electrode material. As demonstrated by the electrochemical measurements, it enhances the transport properties leading to a better ionic diffusion within the high mass loading electrode. This optimization leads to nearly double the specific capacity at 1 $\mathrm{A} / \mathrm{g}$ and strongly improves the capacity retention at higher current densities. Moreover, the full capacity retention after 5000 cycles and the comparison of EIS data before and after the longterm cycling have shown that the protective ionic liquid layer stabilizes the material upon cycling. Additionally, the XRD measurements exhibit that this latter protects the material against oxidation/decomposition during the open-air storage. Finally, this work supports the fact that surface modifications have great influence on the energy storage properties and represent a promising strategy to optimize and control the electrochemical performances of electrode materials.

Notes

The authors declare no competing financial interest.

Acknowledgements:

The authors thank the financial support of Région Nouvelle Aquitaine and of the French National Research Agency (STORE-EX Labex Project ANR-10-LABX-76-01). The authors also want to thank Cathy DENAGE, Emmanuel Petit and Eric LEBRAUD (ICMCB) for her help with SEM, ICP-OES and XRD respectively. 


\section{References:}

1. Y. Shao, M. F. El-Kady, J. Sun, Y. Li, Q. Zhang, M. Zhu, H. Wang, B. Dunn and R. B. Kaner, Chem.

Rev., 118, 9233-9280 (2018) https://pubs.acs.org/doi/10.1021/acs.chemrev.8b00252.

2. N. Choudhary, C. Li, J. Moore, N. Nagaiah, L. Zhai, Y. Jung and J. Thomas, Adv. Mater., 29, 1605336 (2017) http://doi.wiley.com/10.1002/adma.201605336.

3. V. Augustyn, P. Simon and B. Dunn, Energy Environ. Sci., 7, 1597 (2014) http://xlink.rsc.org/?DOI=c3ee44164d.

4. T. Deng, W. Zhang, O. Arcelus, J.-G. Kim, J. Carrasco, S. J. Yoo, W. Zheng, J. Wang, H. Tian, H. Zhang, X. Cui and T. Rojo, Nat. Commun., 8, 15194 (2017) http://www.ncbi.nlm.nih.gov/pubmed/28480885.

5. Z. Liu, R. Ma, M. Osada, K. Takada and T. Sasaki, J. Am. Chem. Soc., 127, 13869-13874 (2005) http://pubs.acs.org/doi/abs/10.1021/ja0523338.

6. Z.-A. Hu, Y.-L. Xie, Y.-X. Wang, L.-J. Xie, G.-R. Fu, X.-Q. Jin, Z.-Y. Zhang, Y.-Y. Yang and H.-Y. Wu, J. Phys. Chem. C, 113, 12502-12508 (2009) https://pubs.acs.org/doi/10.1021/jp8106809.

7. Z. Huang, Y. Zhao, Y. Song, Y. Li, G. Wu, H. Tang and J. Zhao, RSC Adv., 6, 80059-80064 (2016) http://xlink.rsc.org/?DOI=C6RA16063H.

8. S. Ranganatha and N. Munichandraiah, ACS Omega, 3, 7955-7961 (2018)

https://pubs.acs.org/doi/10.1021/acsomega.8b00760.

9. R. Wang, X. Yan, J. Lang, Z. Zheng and P. Zhang, J. Mater. Chem. A, 2, 12724-12732 (2014) http://xlink.rsc.org/?DOI=C4TA01296H.

10. W. Fu, L. Long, M. Wang, Y. Yao, N. Wei, M. Yan, G. Yin, X. Liao, Z. Huang and X. Chen, J. Alloys Compd., 631, 82-85 (2015) http://dx.doi.org/10.1016/j.jallcom.2015.01.089.

11. M. Darbandi, B. Shaabani, A. Alizadeh, P. Yardani, E. Shahryari and M. G. Hosseini, Microporous Mesoporous Mater., 284, 421-426 (2019) https://doi.org/10.1016/j.micromeso.2019.04.048.

12. Y. Gogotsi and P. Simon, Science (80-. )., 334, 917-918 (2011)

http://www.sciencemag.org/cgi/doi/10.1126/science.1213003.

13. A.-L. Brisse, P. Stevens, G. Toussaint, O. Crosnier and T. Brousse, Materials (Basel)., 11, 1178 (2018) http://www.mdpi.com/1996-1944/11/7/1178.

14. C. Wan, L. Yuan and H. Shen, Int. J. Electrochem. Sci., 9, 4024-4038 (2014)

http://www.electrochemsci.org/papers/vol9/90704024.pdf.

15. Z.-H. Huang, Y. Song, D.-Y. Feng, Z. Sun, X. Sun and X.-X. Liu, ACS Nano, 12, 3557-3567 (2018) https://pubs.acs.org/doi/10.1021/acsnano.8b00621.

16. A. D. Jagadale, G. Guan, X. Du, X. Hao, X. Li and A. Abudula, RSC Adv., 5, 56942-56948 (2015) http://xlink.rsc.org/?DOI=C5RA11366K.

17. S. Ranganatha, S. Kumar, T. R. Penki, B. Kishore and N. Munichandraiah, J. Solid State Electrochem., 21, 133-143 (2017) http://dx.doi.org/10.1007/s10008-016-3348-7.

18. J. Olchowka, H. Hagemann, T. Delgado and C. Wickleder, Nanoscale, 10, 19706-19710 (2018) http://pubs.rsc.org/en/Content/ArticleLanding/2018/NR/C8NR06842A.

19. S. S. Moganty, S. Srivastava, Y. Lu, J. L. Schaefer, S. A. Rizvi and L. A. Archer, Chem. Mater., 24, 1386-1392 (2012) https://pubs.acs.org/doi/10.1021/cm300424v.

20. D. Deb and S. Bhattacharya, J. Phys. Chem. C, 121, 6962-6976 (2017) 
https://pubs.acs.org/doi/10.1021/acs.jpcc.6b11845.

21. P. Barpanda, J.-N. Chotard, C. Delacourt, M. Reynaud, Y. Filinchuk, M. Armand, M. Deschamps and J.-M. Tarascon, Angew. Chemie Int. Ed., 50, 2526-2531 (2011)

http://doi.wiley.com/10.1002/anie.201006331.

22. B. G. Choi, M. Yang, S. C. Jung, K. G. Lee, J.-G. Kim, H. Park, T. J. Park, S. B. Lee, Y.-K. Han and Y. S. Huh, ACS Nano, 7, 2453-2460 (2013) https://pubs.acs.org/doi/10.1021/nn305750s.

23. O. Zech, A. Stoppa, R. Buchner and W. Kunz, J. Chem. Eng. Data, 55, 1774-1778 (2010)

https://pubs.acs.org/doi/10.1021/je900793r.

24. J. H. Scofield, J. Electron Spectros. Relat. Phenomena, 8, 129-137 (1976)

https://linkinghub.elsevier.com/retrieve/pii/0368204876800151.

25. M. Jana, P. Sivakumar, M. Kota, M. G. Jung and H. S. Park, J. Power Sources, 422, 9-17 (2019)

https://doi.org/10.1016/j.jpowsour.2019.03.019.

26. H. Xu, B. W. Zeiger and K. S. Suslick, Chem. Soc. Rev., 42, 2555-2567 (2013)

http://xlink.rsc.org/?DOI=C2CS35282F.

27. H. Ebrahimzade, G. R. Khayati and M. Schaffie, Adv. Powder Technol., 28, 2779-2786 (2017) http://dx.doi.org/10.1016/j.apt.2017.08.005.

28. J. Olchowka, T. Tailliez, L. Bourgeois, M. A. Dourges and L. Guerlou-Demourgues, Nanoscale Adv., 1, 2240-2249 (2019) http://xlink.rsc.org/?DOI=C9NA00171A.

29. H. Terraschke, J. Olchowka, E. Geringer, A. V. Rodrigues and C. Wickleder, Small, 14, 1703707

(2018) http://doi.wiley.com/10.1002/smll.201703707.

30. J. Yang, H. Liu, W. N. Martens and R. L. Frost, J. Phys. Chem. C, 114, 111-119 (2010)

http://link.springer.com/10.1007/s11051-011-0269-3.

31. C. D. Wagner, A. V. Naumkin, A. Kraut-Vass, J. W. Allison, C. J. Powell and J. R. J. Rumble, NIST Stand. Ref. Database 20, http:/srdata.nist.gov/xps (2003).

32. Y. Charles-Blin, D. Flahaut, J.-B. Ledeuil, K. Guérin, M. Dubois, M. Deschamps, A.-M. Perbost, L. Monconduit, H. Martinez and N. Louvain, ACS Appl. Energy Mater., 2, 6681-6692 (2019)

https://pubs.acs.org/doi/10.1021/acsaem.9b01191.

33. S. Men, K. R. J. Lovelock and P. Licence, Phys. Chem. Chem. Phys., 13, 15244 (2011)

http://xlink.rsc.org/?DOI=c1cp21053j.

34. P. Vishnu Kamath and M. F. Ahmed, J. Appl. Electrochem., 23, 225-230 (1993)

http://link.springer.com/10.1007/BF00241913.

35. Z. Yu, Z. Cheng, X. Wang, S. X. Dou and X. Kong, J. Mater. Chem. A, 5, 7968-7978 (2017)

http://xlink.rsc.org/?DOI=C7TA00719A.

36. J. S. Ko, M. B. Sassin, D. R. Rolison and J. W. Long, Electrochim. Acta, 275, 225-235 (2018)

https://doi.org/10.1016/j.electacta.2018.04.149.

37. J. S. Ko, V. V. T. Doan-Nguyen, H.-S. Kim, X. Petrissans, R. H. DeBlock, C. S. Choi, J. W. Long and B.

S. Dunn, J. Mater. Chem. A, 5, 18707-18715 (2017) http://xlink.rsc.org/?DOI=C7TA05680J.

38. J. S. Ko, C. S. Choi, B. Dunn and J. W. Long, J. Electrochem. Soc., 164, A2124-A2130 (2017)

https://iopscience.iop.org/article/10.1149/2.1391709jes.

39. J. Vila, L. M. Varela and O. Cabeza, Electrochim. Acta, 52, 7413-7417 (2007) 
https://linkinghub.elsevier.com/retrieve/pii/S0013468607008225.

40. F. Tronel, L. Guerlou-Demourgues, L. Goubault, P. Bernard and C. Delmas, J. Power Sources, 179, 837-847 (2008) https://linkinghub.elsevier.com/retrieve/pii/S0378775308000827.

41. S.-L. Chou, J.-Z. Wang, H.-K. Liu and S.-X. Dou, J. Electrochem. Soc., 155, A926 (2008) https://iopscience.iop.org/article/10.1149/1.2988739.

42. C. Mondal, M. Ganguly, P. K. Manna, S. M. Yusuf and T. Pal, Langmuir, 29, 9179-9187 (2013) https://pubs.acs.org/doi/10.1021/la401752n.

43. G. Du, P. Liu, X. Yang, J. Zhang, X. Wang and X. Sun, RSC Adv., 5, 38324-38329 (2015) http://xlink.rsc.org/?DOI=C5RA02177D.

44. Q. Huang, J. Wang, F. Liu, X. Chang, H. Chen, H. Lin and S. Han, RSC Adv., 6, 16745-16750 (2016) http://xlink.rsc.org/?DOI=C6RA00562D.

45. U. M. Patil, M. S. Nam, J. S. Sohn, S. B. Kulkarni, R. Shin, S. Kang, S. Lee, J. H. Kim and S. C. Jun, J. Mater. Chem. A, 2, 19075-19083 (2014) http://xlink.rsc.org/?DOI=C4TA03953J.

46. J. Yin, H. U. Lee and J. Y. Park, RSC Adv., 6, 34801-34808 (2016) http://xlink.rsc.org/?DOI=C6RA02605B.

47. I. M. Babu, J. J. William and G. Muralidharan, J. Solid State Electrochem., 23, 1325-1338 (2019) http://link.springer.com/10.1007/s10008-019-04223-7.

48. Y. Tang, Y. Liu, S. Yu, S. Mu, S. Xiao, Y. Zhao and F. Gao, J. Power Sources, 256, 160-169 (2014) http://dx.doi.org/10.1016/j.jpowsour.2014.01.064.

49. X. Tan, H. Gao, M. Yang, Y. Luan, W. Dong, Z. Jin, J. Yu, Y. Qi, Y. Feng and G. Wang, J. Alloys Compd., 608, 278-282 (2014) http://dx.doi.org/10.1016/j.jallcom.2014.04.042.

50. T. Mukhiya, B. Dahal, G. P. Ojha, D. Kang, T. Kim, S. H. Chae, A. Muthurasu and H. Y. Kim, Chem. Eng. J., 361, 1225-1234 (2019) https://doi.org/10.1016/j.cej.2019.01.006.

51. C. Wang, H. Qu, T. Peng, K. Mei, Y. Qiu, Y. Lu, Y. Luo and B. Yu, Electrochim. Acta, 191, 133-141 (2016) http://dx.doi.org/10.1016/j.electacta.2016.01.057.

52. T. Zhao, H. Jiang and J. Ma, J. Power Sources, 196, 860-864 (2011) http://dx.doi.org/10.1016/j.jpowsour.2010.06.042.

53. N. C. Maile, S. K. Shinde, R. R. Koli, A. V. Fulari, D. Y. Kim and V. J. Fulari, Ultrason. Sonochem., 51, 49-57 (2019) https://linkinghub.elsevier.com/retrieve/pii/S1350417718306436.

54. J. Liao, X. Wang, Y. Wang, S. Su, A. Nairan, F. Kang and C. Yang, RSC Adv., 8, 17263-17271 (2018) http://xlink.rsc.org/?DOI=C8RA02844C. 


\section{Figures and Tables}
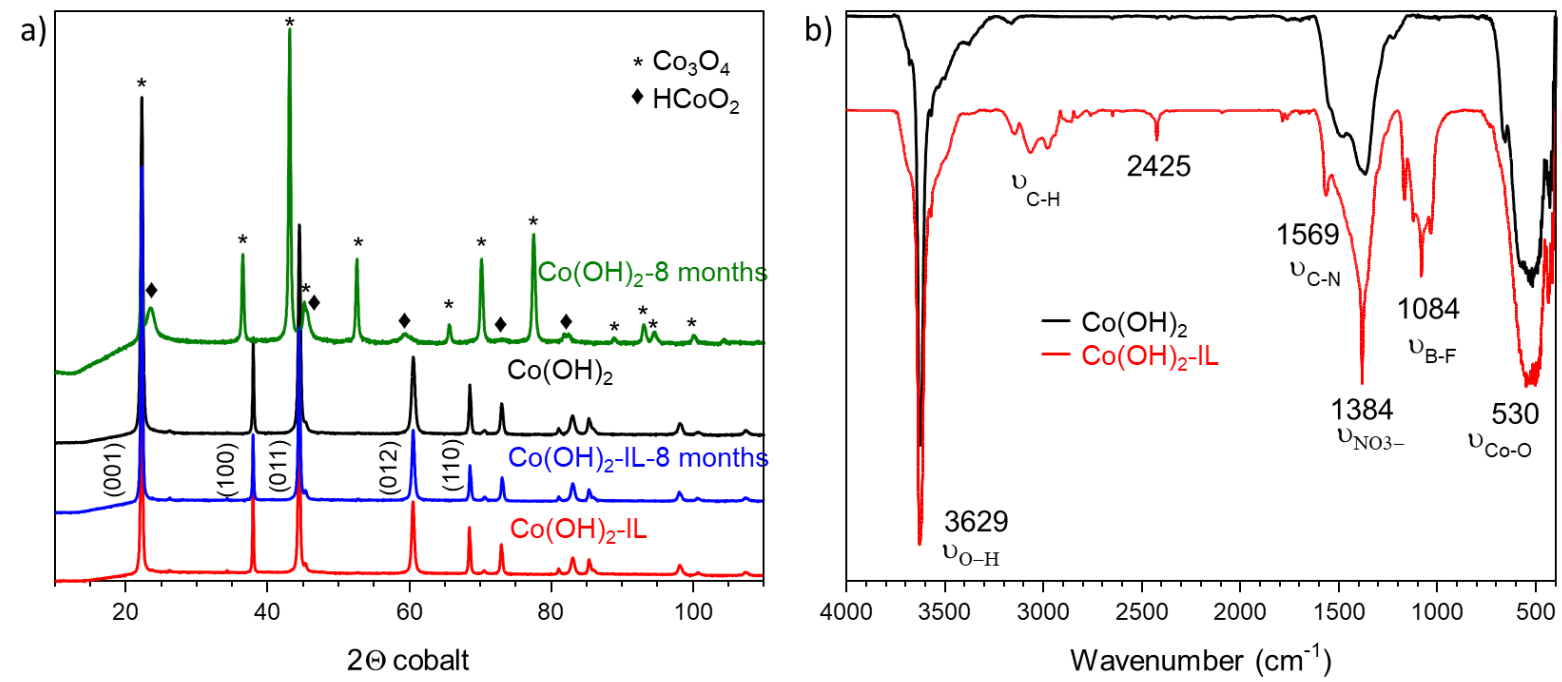

Figure 1. a) XRD pattern of $\mathrm{Co}(\mathrm{OH})_{2}-\mathrm{IL}$ (red) and $\mathrm{Co}(\mathrm{OH})_{2}$ (black), and the materials after 8-month air exposure b) Infrared spectra of $\mathrm{CO}(\mathrm{OH})_{2}-\mathrm{IL}$ (red) and $\mathrm{CO}(\mathrm{OH})_{2}$ (black).

a)
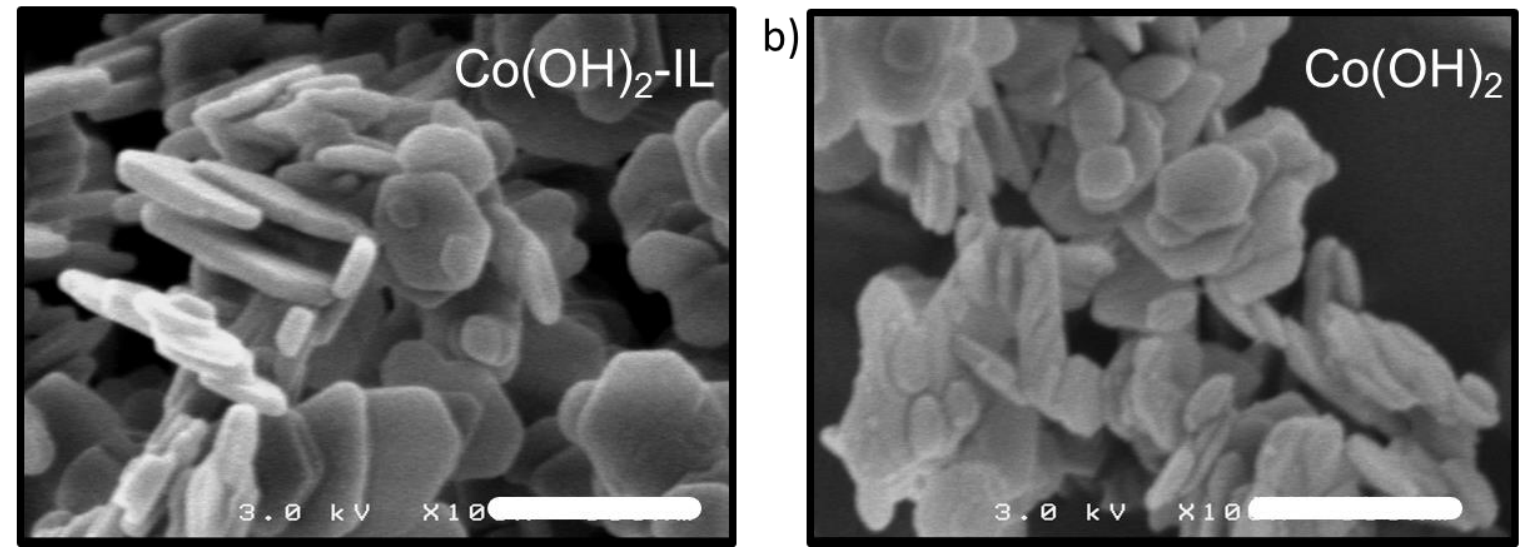

Figure 2. SEM images of a) $\mathrm{CO}(\mathrm{OH})_{2}-\mathrm{IL}$ and b) $\mathrm{CO}(\mathrm{OH})_{2}$, the tick corresponds to $300 \mathrm{~nm}$. 


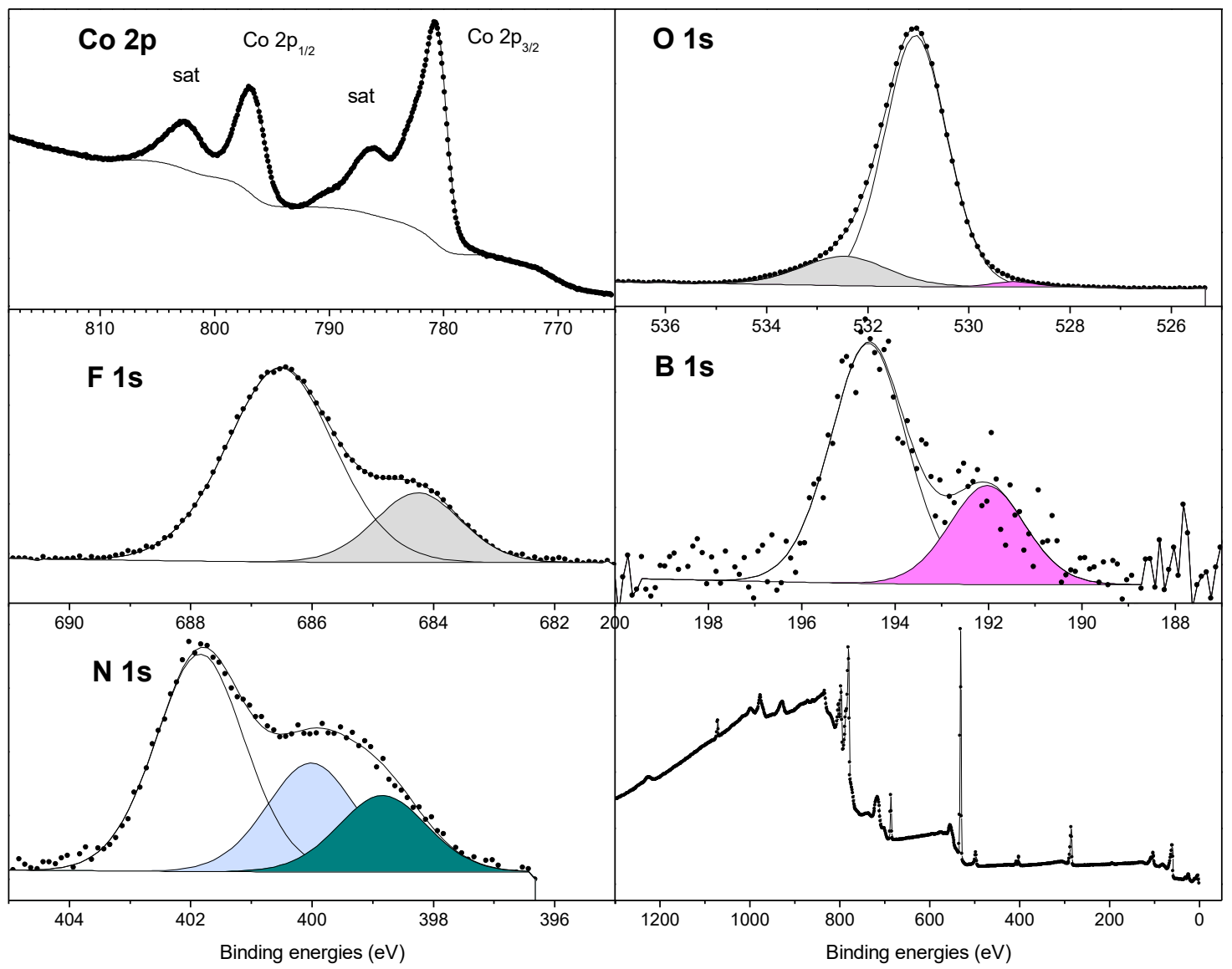

Figure 3. XPS spectra Co 2p, O 1s, F 1s, B 1s and N 1s acquired with $\mathrm{Co}(\mathrm{OH}) 2-\mathrm{IL}$. 
a)
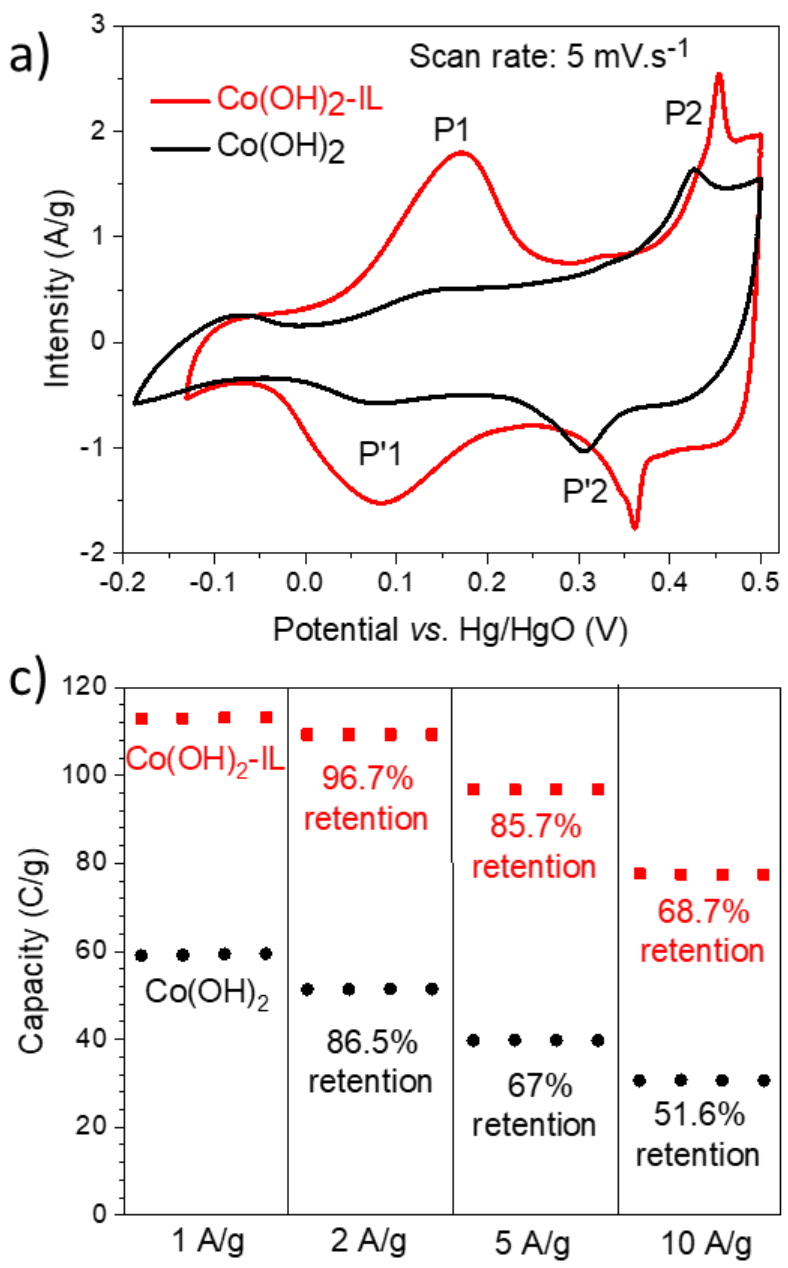

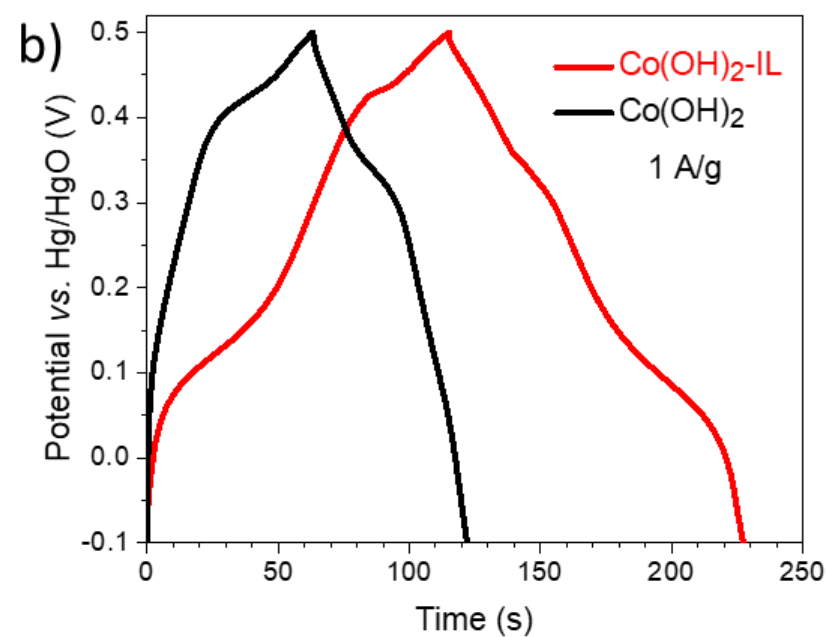

d)

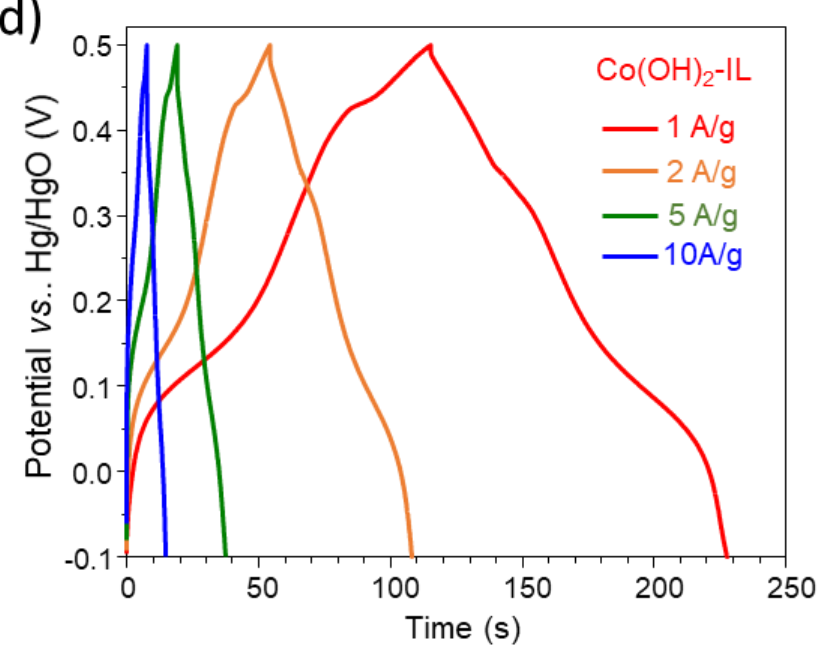

Figure 4. a) Cyclic voltammetry curves measured in $5 \mathrm{M}-\mathrm{KOH}$ at $5 \mathrm{mV} / \mathrm{s}$ for $\mathrm{Co}(\mathrm{OH})_{2}$ and $\mathrm{Co}(\mathrm{OH})_{2}-\mathrm{IL}$ b) Galvanostatic charge and discharge curves of $\mathrm{CO}(\mathrm{OH})_{2}$ and $\mathrm{CO}(\mathrm{OH})_{2}-\mathrm{IL}$ at $1 \mathrm{~A} / \mathrm{g}$ in $5 \mathrm{M}-\mathrm{KOH}$ c) Capacity retention versus current density. 5 cycles at each current density were performed and the 4 last cycles are plotted d) Galvanostatic charge and discharge curves of $\mathrm{CO}(\mathrm{OH})_{2}-\mathrm{IL}$ at different current density. 
a)

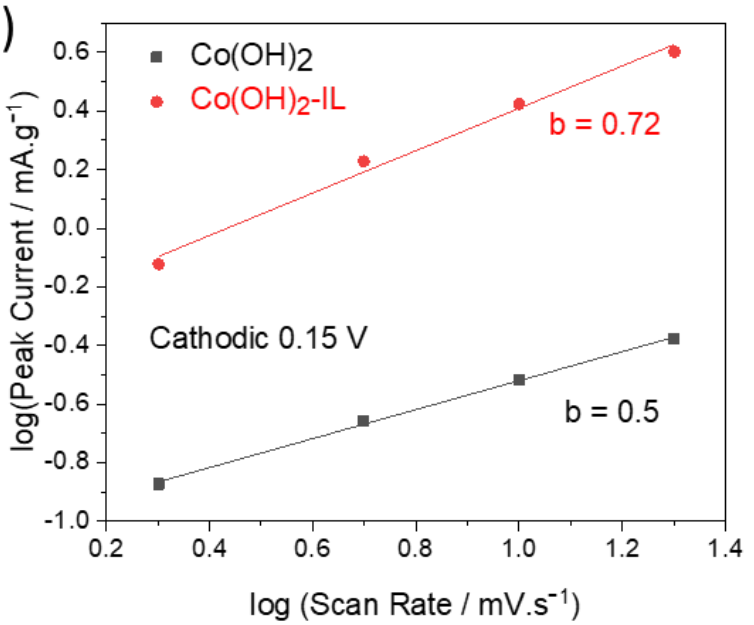

c)

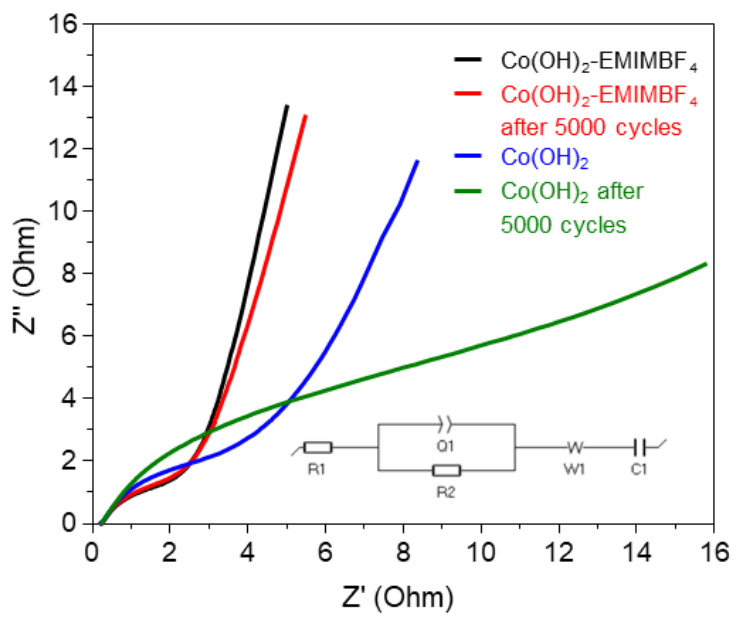

b)
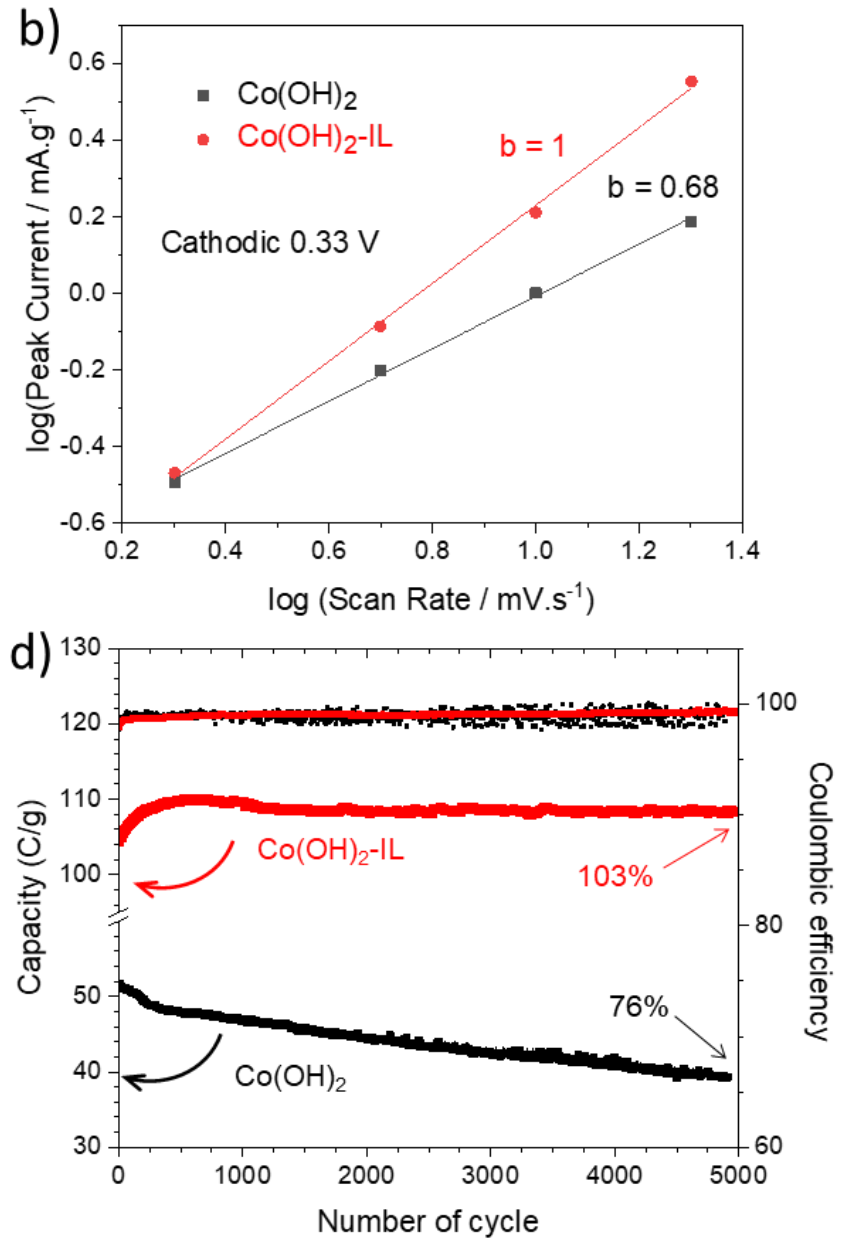

Figure 5. Evolution of the intensity versus the scan rate for $\mathrm{Co}(\mathrm{OH})_{2}$ and $\mathrm{Co}(\mathrm{OH})_{2}-\mathrm{IL}$ a) at the cathodic voltage of $0.15 \mathrm{~V}$ and b) at the cathodic voltage of $0.33 \mathrm{~V}$ c) Nyquist plots of $\mathrm{Co}(\mathrm{OH})_{2}$ and $\mathrm{Co}(\mathrm{OH})_{2}-\mathrm{IL}$ performed before and after $5000 \mathrm{GCD}$ cycles at $2 \mathrm{~A} / \mathrm{g}$ d) Evolution of the capacity and the coulombic efficiency for $\mathrm{Co}(\mathrm{OH})_{2}$ and $\mathrm{Co}(\mathrm{OH})_{2}$ IL upon 5000 cycles performed at $2 \mathrm{~A} / \mathrm{g}$ in $5 \mathrm{M}-\mathrm{KOH}$. 
Table 1: Comparison of the performances of different $\mathrm{Co}(\mathrm{OH})_{2}$ extracted from the literature.

For a better comparison, all the capacity values are reported here in Coulomb per gram.

\begin{tabular}{|c|c|c|c|c|c|}
\hline Phase & Electrolyte & Capacity & Scan rate & Loading mass & Ref \\
\hline$\alpha-\mathrm{Co}(\mathrm{OH})_{2}$ & $6 \mathrm{M} \mathrm{KOH}$ & $430 \mathrm{C} / \mathrm{g}$ & $1 \mathrm{~A} / \mathrm{g}$ & $0.8-1 \mathrm{mg} / \mathrm{cm}^{2}$ & 8 \\
\hline$\overline{B-C o}(\mathrm{OH})_{2}$ & $6 \mathrm{M} \mathrm{KOH}$ & $426 \mathrm{C} / \mathrm{g}(1066 \mathrm{~F} / \mathrm{g}) * 0.4$ & $2 \mathrm{~A} / \mathrm{g}$ & $2 \mathrm{mg} / \mathrm{cm}^{2}$ & 25 \\
\hline$\alpha-\mathrm{Co}(\mathrm{OH})_{2}$ & $6 \mathrm{M} \mathrm{KOH}$ & $245 \mathrm{C} / \mathrm{g}(613 \mathrm{~F} / \mathrm{g}) * 0.4$ & $2 \mathrm{~A} / \mathrm{g}$ & $2 \mathrm{mg} / \mathrm{cm}^{2}$ & 25 \\
\hline $\mathrm{Co}(\mathrm{OH})_{2}$ & $1 \mathrm{M} \mathrm{KOH}$ & $225 \mathrm{C} / \mathrm{g}(562 \mathrm{~F} / \mathrm{g}) * 0.4$ & $0.1 \mathrm{~mA} / \mathrm{g}$ & $0.14 \mathrm{mg} / \mathrm{cm}^{2}$ & 41 \\
\hline$\alpha-\mathrm{Co}(\mathrm{OH})_{2}$ & $2 \mathrm{M} \mathrm{KOH}$ & $343 \mathrm{C} / \mathrm{g}(429 \mathrm{~F} / \mathrm{g}) * 0.8$ & $1 \mathrm{~A} / \mathrm{g}$ & $5 \mathrm{mg} / \mathrm{cm}^{2}$ & 9 \\
\hline $\mathrm{B}-\mathrm{Co}(\mathrm{OH})_{2}$ & $1 \mathrm{M} \mathrm{KOH}$ & $250 \mathrm{C} / \mathrm{g}(416 \mathrm{~F} / \mathrm{g}) * 0.6$ & $1 \mathrm{~A} / \mathrm{g}$ & Not mentioned & 42 \\
\hline$\alpha-\mathrm{Co}(\mathrm{OH})_{2}$ & $1 \mathrm{M} \mathrm{LiOH}$ & $193 \mathrm{C} / \mathrm{g}(386 \mathrm{~F} / \mathrm{g}) * 0.5$ & $0.4 \mathrm{~A} / \mathrm{g}$ & $2.5 \mathrm{mg} / \mathrm{cm}^{2}$ & 16 \\
\hline $\mathrm{B}-\mathrm{Co}(\mathrm{OH})_{2}$ & $6 \mathrm{M} \mathrm{KOH}$ & $108.5 \mathrm{C} / \mathrm{g}(217 \mathrm{~F} / \mathrm{g}) * 0.5$ & $0.1 \mathrm{~A} / \mathrm{g}$ & Not mentioned & 43 \\
\hline $\mathrm{B}-\mathrm{Co}(\mathrm{OH})_{2}$ & $6 \mathrm{M} \mathrm{KOH}$ & $38 \mathrm{C} / \mathrm{g}(94 \mathrm{~F} / \mathrm{g}) * 0.4$ & $1 \mathrm{~A} / \mathrm{g}$ & $2 \mathrm{mg} / \mathrm{cm}^{2}$ & 44 \\
\hline $\begin{array}{l}\text { B-Co }(\mathrm{OH})_{2} \\
\text { /graphene }\end{array}$ & $6 \mathrm{M} \mathrm{KOH}$ & $192 \mathrm{C} / \mathrm{g}(480 \mathrm{~F} / \mathrm{g}) * 0.4$ & $1 \mathrm{~A} / \mathrm{g}$ & $2 \mathrm{mg} / \mathrm{cm}^{2}$ & 44 \\
\hline $\begin{array}{l}\text { B-Co(OH })_{2} \\
\text { /graphene }\end{array}$ & $6 \mathrm{M} \mathrm{KOH}$ & $216.5 \mathrm{C} / \mathrm{g}(433 \mathrm{~F} / \mathrm{g}) * 0.5$ & $0.1 \mathrm{~A} / \mathrm{g}$ & Not mentioned & 43 \\
\hline $\begin{array}{l}\text { B-Co(OH })_{2} \\
\text { /graphene }\end{array}$ & $1 \mathrm{M} \mathrm{KOH}$ & $412 \mathrm{C} / \mathrm{g}(1030 \mathrm{~F} / \mathrm{g}) * 0.4$ & $9.09 \mathrm{~A} / \mathrm{g}$ & $0.92 \mathrm{mg} / \mathrm{cm}^{2}$ & 45 \\
\hline $\begin{array}{l}\mathrm{Co}(\mathrm{OH})_{2} / \text { grap } \\
\text { hene/chitosan }\end{array}$ & $2 \mathrm{M} \mathrm{KOH}$ & $257 \mathrm{C} / \mathrm{g}(367 \mathrm{~F} / \mathrm{g}) * 0.7$ & $1 \mathrm{~A} / \mathrm{g}$ & $2.6 \mathrm{mg} / \mathrm{cm}^{2}$ & 46 \\
\hline $\begin{array}{l}\beta-\mathrm{Co}(\mathrm{OH})_{2} \\
/ \mathrm{CMC}\end{array}$ & $2 \mathrm{M} \mathrm{KOH}$ & $303 \mathrm{C} / \mathrm{g}$ & $1 \mathrm{~A} / \mathrm{g}$ & $1 \mathrm{mg} / \mathrm{cm}^{2}$ & 47 \\
\hline $\mathrm{B}-\mathrm{Co}(\mathrm{OH})_{2}$ & $6 \mathrm{M} \mathrm{KOH}$ & $175.5 \mathrm{C} / \mathrm{g}(351 \mathrm{~F} / \mathrm{g}) * 0.5$ & $1 \mathrm{~A} / \mathrm{g}$ & $1.8 \mathrm{mg} / \mathrm{cm}^{2}$ & 48 \\
\hline $\mathrm{B}-\mathrm{Co}(\mathrm{OH})_{2}$ & $1 \mathrm{M} \mathrm{KOH}$ & $75 \mathrm{C} / \mathrm{g}(166.7 \mathrm{~F} / \mathrm{g}) * 0.45$ & $1 \mathrm{~A} / \mathrm{g}$ & $1.65 \mathrm{mg} / \mathrm{cm}^{2}$ & 49 \\
\hline $\begin{array}{l}\mathrm{B}-\mathrm{Co}(\mathrm{OH})_{2} \\
/ \mathrm{CNF}\end{array}$ & $2 \mathrm{M} \mathrm{KOH}$ & $534 \mathrm{C} / \mathrm{g}(1186 \mathrm{~F} / \mathrm{g}) * 0.45$ & $1 \mathrm{~A} / \mathrm{g}$ & $4 \mathrm{mg} / \mathrm{cm}^{2}$ & 50 \\
\hline $\begin{array}{l}\mathrm{B}-\mathrm{Co}(\mathrm{OH})_{2} \\
/ \mathrm{CNT}\end{array}$ & $2 \mathrm{M} \mathrm{KOH}$ & $228.5 \mathrm{C} / \mathrm{g}$ & $1 \mathrm{~A} / \mathrm{g}$ & $1.86 \mathrm{mg} / \mathrm{cm}^{2}$ & 51 \\
\hline$\alpha-\mathrm{Co}(\mathrm{OH})_{2}$ & $1 \mathrm{M} \mathrm{KOH}$ & $260 \mathrm{C} / \mathrm{g}(473 \mathrm{~F} / \mathrm{g}) * 0.55$ & $2 \mathrm{~A} / \mathrm{g}$ & $0.74 \mathrm{mg} / \mathrm{cm}^{2}$ & 52 \\
\hline$\alpha-\mathrm{Co}(\mathrm{OH})_{2}$ & $0.5 \mathrm{M} \mathrm{KOH}$ & $218.4 \mathrm{C} / \mathrm{g}(273 \mathrm{~F} / \mathrm{g}) * 0.8$ & $0.75 \mathrm{~A} / \mathrm{g}$ & $1.33 \mathrm{mg} / \mathrm{cm}^{2}$ & 53 \\
\hline $\mathrm{B}-\mathrm{Co}(\mathrm{OH})_{2}$ & $1 \mathrm{M} \mathrm{KOH}$ & $534.7 \mathrm{C} / \mathrm{g}(891.2 \mathrm{~F} / \mathrm{g}) * 0.6$ & $1 \mathrm{~A} / \mathrm{g}$ & $5.42 \mathrm{mg} / \mathrm{cm}^{2}$ & 54 \\
\hline $\mathrm{Co}_{2}(\mathrm{OH})_{3} \mathrm{Cl}$ & $3 \mathrm{M} \mathrm{KOH}$ & $292.5 \mathrm{C} / \mathrm{g}(450 \mathrm{~F} / \mathrm{g}) * 0.65$ & $2 \mathrm{~A} / \mathrm{g}$ & $\sim 0.5 \mathrm{~g} / \mathrm{cm}^{2}$ & 17 \\
\hline B-Co(OH)2-IL & 5M КОН & $113.5 \mathrm{C} / \mathrm{g}$ & $1 \mathrm{~A} / \mathrm{g}$ & $13 \mathrm{mg} / \mathrm{cm}^{2}$ & This work \\
\hline
\end{tabular}


Table 2: Binding Energies (eV) and atomic percentages (at. \%) of $\mathrm{Co}(\mathrm{OH})_{2}-\mathrm{IL}$.

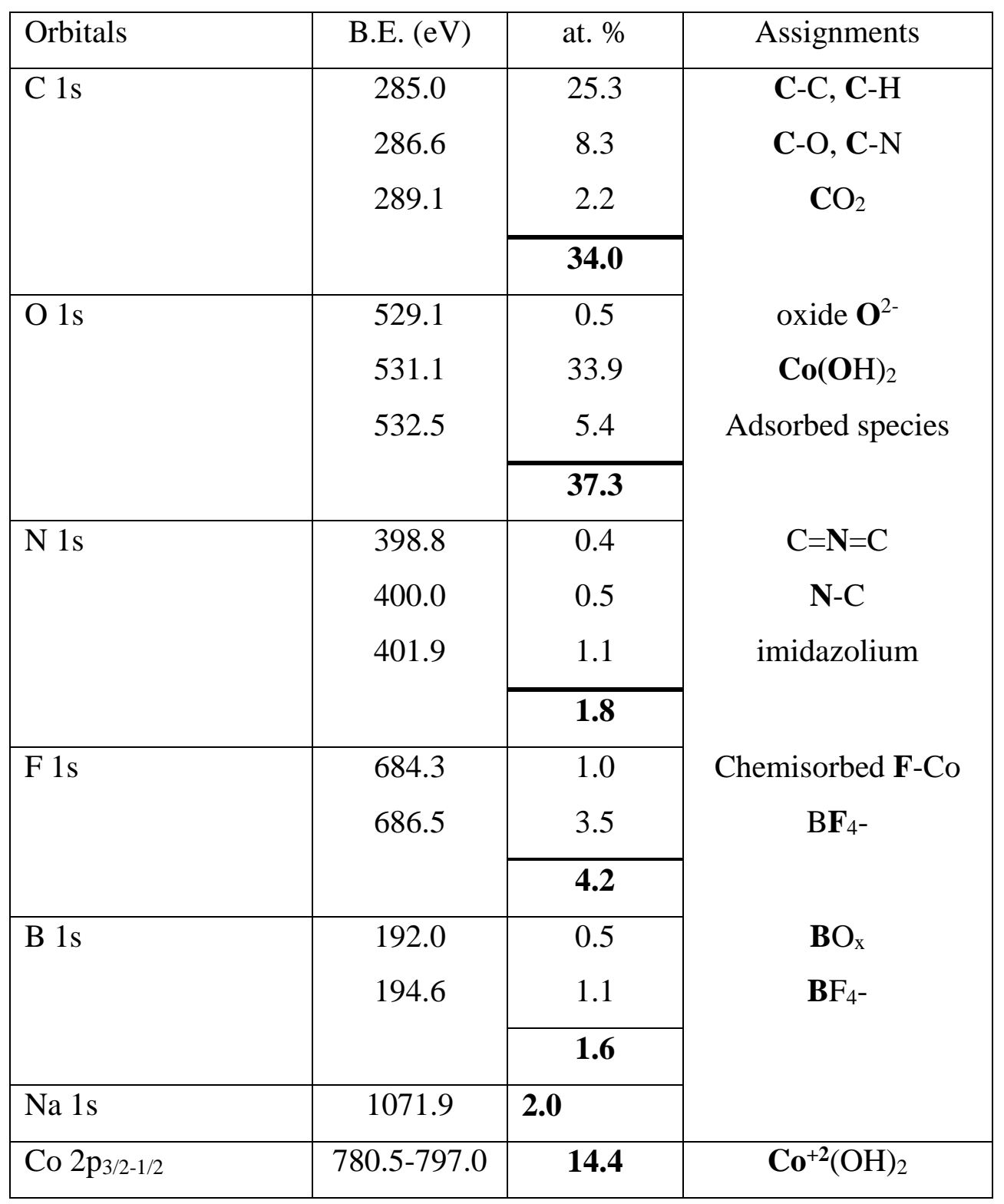

